\section{Response to Pross}

SIR

We of the German Association on the Political Abuse of Psychiatry agree with the statements made by Christian Pross in his paper, 'Breaking through the postwar coverup of Nazi doctors in Germany' (1) to a large extent. The attitude of covering up was experienced by me as late as 1989 , a few weeks after the Deutsche Ärztetag, the representative body of German doctors, had managed openly to acknowledge the profession's guilt in some of the most atrocious Nazi crimes.

At the World Congress of Psychiatry in Athens I brought up the subject of psychiatric abuse in the USSR and the, at times, rather reluctant resistance against it. When I mentioned in this context that 'there has only recently been wider and deeper discussion amongst doctors about the terrors of the Nazi era in my country', I was publicly accused of not telling the truth by the then acting president of the German Psychiatric Association who-in spite of the fact that his own life had been affected by Nazi persecution - claimed that much had been done by German doctors to debate this issue.

The truth seems to be somewhere in the middle between this assertion and the opinion of Pross who denies any sense of remorse within the medical profession in postwar Germany and claims all activity to redress these attitudes for his own faction.

As a student in the early sixties I read A Mitscherlich's and F Mielke's book Medizin ohne Menschlichkeit (Medicine Without Humanity) which at that time was easily available as a paperback. Psychiatrie der Verfolgten (Psychiatry of the Persecuted) by $\mathrm{W}$ von Baeyer, $\mathrm{H}$ Häfner and K P Kisker, published in 1964, also appeared to me to be a serious attempt to 'digest and overcome'. Believing that the most urgent tasks had been accomplished, I and other colleagues, at the beginning of the seventies, turned against current criminal actions within the medical profession and against a current 'complicity of silence and coverup' which, in effect, was condoning those criminal actions.

Faced with numerous reports of abuses of psychiatry in the Soviet Union at that time we became engaged in fighting against such abuses and on behalf of their victims accomplished for them quite a few things but never managed in the following 20 years to have the Deutscher Ärztetag name the Soviet Union as the centre of such abuses and stop the perpetrators by singling them out.

Of course, the Ärztetag has always been in 'good company' since large parts of the intellectual elite of this country ignored the crimes of the Soviet system at that time. Pross's 'national conference of doctors and health workers', the 'Gesundheitstag', and most of the leftist doctors, did so as well. To be sure, many more aspects of Nazi terror were revealed by these groups in the eighties. And they showed concern also about current events, such as victims of torture - particularly when they came from Chile, Turkey or South Africa.

Those who interceded for victims of psychiatric abuse in the Soviet Union, however, were silenced or insulted by these groups; amongst those who were so insulted was Professor Walter von Baeyer, the former Vice-President of the World Psychiatric Association (1966-1971). 'Anti-Communism' was still the mildest form of insinuation. The 'complicity of silence and coverup in the German medical profession' was manifested in this respect in various forms by various factions.

Since Pross highlighted (2) Professor Toellner's lecture at the Deutsche Ärztetag in 1989 as a turning point towards a sincere confrontation with the Nazi past by German doctors, Professor
Toellner's conclusions should not be omitted: 'Where the doctor allows himself to be used as an instrument', he concluded, 'where the doctor allows himself himself to be deprived of his indivisible responsibility for his professional conduct and decisions, or delegates them, where the doctor does not protect and preserve life but extradites and kills, where the doctor usurps the decision about the value of a human life ..., where the medical profession does not secure and protect the ethical standards of medicaf conduct, there the doctors jeopardise their profession, their mission and themselves. The history of doctors in the "Third Reich" teaches us so ...'.

\section{References}

(1) Pross C. Breaking through the postwar coverup of Nazi doctors in Germany. Fournal of medical ethics [supplement] 1991; 4: 13-16.

(2) See reference (1): 15.

DR FRIEDRICH WEINBERGER,

German Association on the Political Abuse of Psychiatry, Walter-von-BaeyerGesellschaft eV, President, Maximilianstr 6, W8130 Starmberg, Germany.

\section{HIV-positive surgeon}

SIR

The publicity surrounding yet another case of a surgeon who may be HIVpositive, has highlighted public anxiety and perhaps the shortcomings of present guidelines pertaining to the HIV status of practising doctors.

There are two interrelated aspects to address. Firstly, those individuals who are not HIV-positive, but are within a higher risk category for contracting infection. Secondly, those who have already sero-converted. 